Canadian

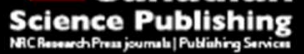

Canadian Journal of Civil Engineering Revue canadienne de génie civil

\title{
Steady and Unsteady Pressure Scour under Bridges at Clear-Water Conditions
}

\begin{tabular}{|r|l|}
\hline Journal: & Canadian Journal of Civil Engineering \\
\hline Manuscript ID & cjce-2015-0385.R2 \\
\hline Manuscript Type: & Article \\
\hline Date Submitted by the Author: & 14-Jan-2016 \\
\hline Complete List of Authors: & Kumcu, S.Yurdagul; University of Mississippi, NCCHE \\
\hline Keyword: & $\begin{array}{l}\text { pressurized flow, bridge scour, unsteady flow, temporal development, } \\
\text { sediment transport }\end{array}$ \\
\hline \multicolumn{2}{|l}{} \\
\hline
\end{tabular}


Steady and Unsteady Pressure Scour under Bridges at Clear-Water Conditions

\section{Serife Yurdagul Kumcu}

Assist. Prof. Dr., Civil Engineering Department, Necmettin Erbakan University, Konya, Turkey

(e-mail: yurdagulkumcu@gmail.com) 


\begin{abstract}
Bridges are vital components of the transportation network and if they are destroyed or damaged during a flooding, they isolate communities and limits movement of supplies and emergency services. Evaluating their constructional stability and structural response after a flood event is critical for bridge safety. Bridge studies are usually designed with an assumption of an open channel flow condition, but the flow regime can switch to pressure flow if the downstream edge of a bridge deck is partially or totally submerged during a large flood.

The main goal of this paper is to study the pressurized flow scour under a bridge deck and downstream deposition which results from eroded sediment material governed by both steady and unsteady clear-water flow conditions. Experimental conditions used in this study involve clear-water scour of a sand bed of given median sediment size $\mathrm{d}_{50}=0.90 \mathrm{~mm}$ and sediment uniformity $\sigma_{\mathrm{g}}=1.29$, an approach flow characterized by a flow depth and velocity, a rectangular-shaped bridge deck, and a stepwise flood hydrograph defined by its time to peak and peak discharge. Different flow conditions were considered in confined flow under the bridge deck.

Relationship between pressure-flow scour and flow conditions is presented and discussed under the obtained experimental data. Additionally, effects of single-peaked stepwise flow hydrographs (unsteady flow conditions) on bridge pier scour depth are investigated under clear-water pressure-flow conditions, whereas previous researches mainly focused on the equilibrium pressure scour under steady flow conditions.
\end{abstract}

Keywords: pressured scour, clear-water flow, unsteady flow, temporal development, sediment transport 


\section{Introduction}

Pressurized flow conditions under a bridge structure can be initiated if the approach flow depth rises above the bridge deck. Unlike open channel flows, pressure-flows create a severe scourability potential because scouring the channel bed is one of the only ways to dissipate the energy when passing a given discharge in pressurized flow (Guo et al. 2009). Previous researches on pressurized flow scour are not too much and include the studies of Abed (1991), Jones et al. (1993), Arneson (1997), Umbrell et al. (1998), Lyn (2008), Guo et al. (2009), Hahn and Lyn (2010), Zhai (2010), and Melville (2014). Based on the study of Arneson (1997), an equation named HEC-18 states

$\frac{z_{s}}{h_{a}}=-5.08+1.27\left(\frac{h_{a}}{h_{b}}\right)+4.44\left(\frac{h_{a}}{h_{b}}\right)^{-1}+0.19\left(\frac{V_{b}}{V_{c}}\right)$

where $z_{s}=$ depth of equilibrium or ultimate scour; $h_{a}=$ upstream flow depth; $h_{b}=$ initial (prior to scour) distance between the bridge low chord and the undisturbed bed at the bridge section; $V_{b}=$ initial (prior to scour) velocity through the bridge opening and $V_{c}=$ critical velocity of the bed material (Figure 1). Arneson (1997) defined critical velocity $V_{c}$ associated with incipient sediment motion which is based on $h_{a}$ as

$$
V_{c}=1.52 \sqrt{g(s-1) d_{50}}\left(\frac{h_{a}}{d_{50}}\right)^{1 / 6}
$$

in which $s=$ specific gravity of sediment material; $g=$ acceleration due to gravity; and $d_{50}=$ median diameter of sediment particles.

Umbrell et al. (1998) proposed the following equation to estimate pressure scour depth as

$$
\frac{z_{s}}{h_{a}}=1.102\left(\frac{V_{a}}{V_{c}}\right)^{0.603}-\frac{h_{b}}{h_{a}}
$$

where $V_{a}=$ mean upstream approach flow velocity. According to Umbrell et al. (1998), it should be noted that $V_{c}$ is calculated by Eqn.(2) using the constant of 1.58 rather than 1.52 .

Lyn (2008) re-examined HEC-18 and found to exhibit unsatisfactory behaviour due to an ill-chosen original model equations. He proposed a design equation based on a one-sided predictive interval as

$$
\frac{z_{s}}{h_{a}}=\min \left[0.21\left(\frac{V_{b}}{V_{c}}\right)^{2.95}, 0.6\right]
$$


Guo et al. (2009) studied both analytically and experimentally pressure flow under bridges having girders in clear-water conditions. Experiments revealed that (1) equilibrium scour profiles under the a bridge are more or less consistent across the channel width, (2) the maximum scour position is located under the bridge and located at a location 15.4 percent of the deck width from the downstream edge of the deck, (3) scour begins at approximately one deck width upstream of the bridge, and deposition begins at approximately 2.5 deck widths downstream of the bridge. They also divided analytically bridge scour into three cases: downstream unsubmerged, partially submerged, and totally submerged.

Recently, Zhai (2010) investigated experimentally time-dependent scour depth under bridge decks in totally submerged flow conditions using two uniform sediment sizes and one model bridge deck with three different inundation levels. A semi-empirical model for estimating time-dependent scour was then presented based on the mass conservation of sediment, which agrees well with the collected data.

All previous researches given above on pressure-scour covered only for steady flow conditions using unique peak discharge value. However, the general practice of employing peak flow discharge to evaluate the maximum scour depth for design may be questioned because the maximum scour depth occurring under a flood hydrograph can be much smaller than that calculated using peak-flow discharge. In other words, using the peak-flow discharge for design can greatly overestimate the maximum scour depth in comparison to the actual conditions under the flood hydrograph. Therefore, when the flow unsteadiness is pronounced, the temporal effect on scour depth should be considered (Chang et al. 2004; Lu et al. 2008).

Besides there is a limited number of studies on bridge scour under pressure flow conditions, the cases considering flow unsteadiness were never considered in the previous studies. Oliveto and Hager (2005) stated that although bridge foundations fail mainly during floods, the effect of unsteady hydraulic load on bridge piers and abutments has received no systematic attention.

Compared to the scour research studies on piers and abutments, pressure-flow scour (sometimes called as vertical contraction scour) has received less attention scientifically. The main goal of this paper is to study the pressurized flow scour under a bridge deck experimentally, governed by both steady and unsteady clear-water flow conditions. 


\section{Theoretical Considerations}

Non-dimensional equilibrium (or ultimate) pressure-scour depth under a bridge deck as given in Figure 1 can be expressed as a function of the following non-dimensional form of relevant parameters provided that clear-water conditions at the upstream of the bridge deck, single uniform sand size, and constant bridge length along the streamwise direction:

$\frac{z_{s}}{h_{a}}=f\left(\frac{h_{b}}{h_{a}}, \frac{V_{b} t}{L}, \frac{V_{b}}{V_{c}}\right)$

where, $h_{a}, V_{b}, V_{c}, h_{b}$, and $L$, are as previously defined and $t$ is time. Herein, $h_{b} / h_{a}$ is the submergence ratio of the bridge deck, $V_{b} t / L$ is the non-dimensional time parameter, and $V_{b} / V_{c}$ is the flow intensity under the bridge deck. In this study the non-dimensional parameter representing temporal scour development $V_{b} t / L$ is replaced with another non-dimensional time parameter of $t / \tau$ as given by Hahn and Lyn (2010) in which $\tau$ is a time-scale of scour development and will be defined in detail in the proceeding sections. Then, Equation (5) can be rearranged as:

$\frac{z_{s}}{h_{a}}=f\left(\frac{h_{b}}{h_{a}}, \frac{t}{\tau}, \frac{V_{b}}{V_{c}}\right)$

\section{Experimental Conditions}

The experiments were performed at the Hydraulics Laboratory of State Hydraulic Works (DSI) of Turkey, Ankara. A rectangular flume with transparent walls, $30 \mathrm{~m}$ long and $1.5 \mathrm{~m}$ wide, was filled with erodible uniform sediment to conduct experiments (Figure 2). Sand was used as sediment material with median size of $d_{50}=0.90$ $\mathrm{mm}$ and sediment uniformity coefficient of $\sigma=1.29$. The flume slope was 0.001 and a recessed section, $7 \mathrm{~m}$ long; containing sediment was located $13 \mathrm{~m}$ downstream of the flume inlet. The flume flow was supplied from a constant-head water tank and measured by a sharp-crested rectangular weir. The outflow was directed to the laboratory return channel, from where it was pumped to the water tank for re-supply. The flow depth was read with a conventional point gage, typically to $\pm 0.5-1.0 \mathrm{~mm}$, depending on the local water surface turbulence. The sand layer thickness was $0.50 \mathrm{~m}$ in the working reach and $0.10 \mathrm{~m}$ along the rest of the channel. At the end of the each test the channel was drained gradually without causing any disturbance to the scour pattern. After each experiment the extent of the scour hole was measured by a point gage along the centerline of the test channel. 
As pressure flow under even a simple bridge deck has not been clarified yet, the localized effect of bridge piers and abutments were not included during the experiments in the present study. The modeled bridge deck was of simple rectangular form having the length in the streamwise direction, $L=0.30 \mathrm{~m}$ as shown in Fig. 2 without considering a real bridge structure with bottom girders. The deck elevation was adjustable permitting the deck to have two bridge opening heights of $h_{b}=5$ and $7.5 \mathrm{~cm}$. For these two $h_{b}$ values four discharges were applied in the experiments $(Q=40,45,50$ and $55 \mathrm{lt} / \mathrm{s}$ with the corresponding mean upstream approach velocities varying between $V_{a}=0.232-0.286 \mathrm{~m} / \mathrm{s}$ ). As the maximum scour often results from clear water flow with a critical approach flow velocity for bed-load motion, experiments were conducted under clear-water flow conditions for both steady and unsteady flows. Next, steady and unsteady flow results were compared with each other. Equation (2) was used to determine whether live-bed or clear-water conditions existed upstream of the bridge deck section. The critical flow velocity $V_{c}$ was calculated from Eq.(2) as $V_{c}=0.414 \mathrm{~m} / \mathrm{s}$ which corresponds to a maximum allowable velocity in the upstream of the test channel. The maximum test duration was 32 hours of continuous run for the experiments which were conducted under clear-water steady flow conditions. The data for $h_{b}=7.5 \mathrm{~cm}$ and $Q=401 / \mathrm{s}$ was excluded from the experimental study since the flow conditions below the bridge deck was below the critical condition for sediment motion.

In unsteady flow conditions, the prescribed stepwise discharge hydrographs as given in Figure 3 were applied to maintain unsteady clear-water flow conditions in the test channel. The scour pattern, which developed in the test section, was obtained by performing eight hours continuous run under clear-water flow conditions. In each hydrograph, the peak discharge was set to $50 \mathrm{l} / \mathrm{s}$ while time to peak $t_{p}$ and step-size of hydrographs were varied. Since previous studies showed that the recession limb of flood hydrograph plays a minor role in the scouring process, only the effect of the rising limb of a stepwise hydrograph is addressed in this study (Chang et al. 2004; Oliveto and Hager 2005; Lai et al. 2009; Hager and Unger 2010). The experimental conditions used in the present study are given in Table 1. 


\section{Analysis of Results}

4.1 Steady flow

4.1.1 Temporal evolution of bed morphology

Pressurized scour mechanism starts when the vertical constriction of the flow area by the bridge deck with decreasing cross-sectional area and increasing the corresponding flow velocity through the opening. Any increase in flow velocity attributes additional shear stress on the channel bed causing an increase in bed scour in the area of contraction region. As bed material is transported out of the contraction region, the cross-sectional area increases so that the velocity decreases. Eventually, the flow velocity falls below the threshold velocity of the bed material and scour equilibrium is reached.

Horizontal coordinates, $x$ and $y$, are normalized by the width of the bridge $L$, so that $x / L=0$ and 1 designate the streamwise beginning and end of the model bridge. The vertical coordinates are scaled with the depth of submergence $h_{s}$.

The temporal developments of the scour holes in steady flow conditions are shown in Figures 4 and 5 for $h_{b}=0.075 \mathrm{~m}$ and $0.050 \mathrm{~m}$, respectively, where streamwise profiles of bed elevations for various values of $t$ are plotted. The profiles shown were all measured along the centerline of the test channel, since the maximum measured scour depth $z_{s}=\left(z_{m}\right)_{s}$ had minimum side effects.

In general, it can be said that the scour geometry is $2 \mathrm{D}$ and the shapes of the scour holes are almost identical as time elapses. It can be also observed that the scour hole develops rapidly from $t=0$ to $0.5 \mathrm{~h}$, which means that the rate of change of scour depth is very high at the beginning of scour process. However, the change of scour depth is negligible after $t=30$ to $32 \mathrm{~h}$ which implies that an equilibrium scour hole is attained approximately at $t=32 \mathrm{~h}$. The position of the maximum scour depth is near to the downstream part of the bridge deck. Figure 4 indicates that the limit of scour hole develops between $-0.5<x / L<1.5$ for $h_{b} / h_{a} \approx 0.60$. On the other hand, for $h_{b} / h_{a} \approx 0.40$ as given in Figure 5, limits of scour hole extends further downstream and develops approximately between $0<x / L<3$.5. Similar scour profiles were obtained from Guo et al. (2009) for a girder type bridge deck model indicating that the scour occurred generally between $-1.5<x / L<1$.5. For both studies, i.e. the present study and Guo et al. (2009), the occurrence of the maximum scour depths was observed under the bridge deck section $(0 \leq x / L \leq 1)$ for all test durations studied. However, in the study of Hahn and Lyn (2010), the scour hole development occurred next to the section downstream of the bridge deck $(x / L>1)$. Comparing Figures 4 and 5 on 
the basis of bridge height $h_{b}$, it can be easily observed that as the bridge opening height $h_{b}$ decreases then $V_{b} / V_{c}$ increases and as a result scour hole geometry moves along the downstream direction.

Depositional patterns of the scoured sediment material propagating dune-like bed forms along the downstream direction were also measured in all tests. The sediments eroded from the scour hole were deposited and as a consequence the elevation of the channel bed increased. Similar to the scour profiles, 2D dune-like bed forms downstream of the bridge deck due to pressurized-scour process as a component of scour were observed along the depositional patters. In Figure 4, the extent of deposition zone developed between $1.5<x / L<8.1$ for $h_{b} / h_{a} \approx 0.60$. As shown in Figure 5, when the velocity under the bridge section increases, the deposition zone extends further downstream (i.e. $3.5<x / L<10.7$ ) for $h_{b} / h_{a} \approx 0.40$.

Figure 6 displays the temporal evolution of the maximum scour depth $\left(z_{m}\right)_{s}$ under the bridge deck as a function of approach flow intensity ratios as $V_{a} / V_{c}=0.64$ and 0.69 for constant bridge heights of $h_{b}=0.050$ and $0.075 \mathrm{~m}$, respectively. For those cases, as time elapses, the maximum scour depth increases but the rate of change decreases and tends to zero as an equilibrium scour approaches. It is apparently observed from Figure 6 that as approaching flow intensity increases the maximum scour depth $\left(z_{m}\right)_{s}$ increases as well. In addition, the scour depth increases as the bridge height, $h_{b}$, decreases, or deck inundation level $h_{a}-h_{b}$ increases. Figure 7 shows temporal evolution of the maximum scour depth $\left(z_{m}\right)_{s}$ as a function of flow intensity ratios under bridge deck as $V_{b} / V_{c}=1.60$ and 1.07 for the constant approaching flow intensity $V_{a} / V_{c}=0.64$ and $V_{b} / V_{c}=1.77$ and 1.18 for the constant approaching flow intensity $V_{a} / V_{c}=0.69$, respectively. For a given constant $V_{a} / V_{c}$ the maximum scour depth increases with the increase of flow intensity under the bridge deck $V_{b} / V_{c}$. Consequently, Figures 6 and 7 indicate that the maximum scour depth $\left(z_{m}\right)_{s}$ increases when either of $V_{b} / V_{c}$ or $V_{a} / V_{c}$ increases, provided that $V_{b}$ is the main dominating flow parameter contributing the scour phenomenon which should be higher than $V_{c}$ in order to initiate the scour process.

In order to analyse the variation of non-dimensional scour parameters $\left(z_{m}\right)_{s} / h_{s}$ and $\left(x_{m}\right)_{s} / h_{s}$ with nondimensional time parameter $t / \tau$, time parameter $\tau$ should be initially defined. In this study, time scale of the scour development was calculated from the equation of Hahn and Lyn (2010);

$$
\tau=\frac{h_{s}^{2}}{\theta_{u}^{n_{s}} \sqrt{g(s-1) d_{50}^{3}}}
$$

where $\theta_{u}=$ Shields parameter upstream of the bridge structure $\theta_{u}=u_{*}^{2} /\left[g(s-1) d_{50}\right], n_{s}=$ a constant, and $u *=$ shear velocity. 
The constant $n_{s}$ varies between 1.5 and 2.5 and can be selected as 2.5 in this study to obtain much likely time scale value, i.e. $\tau=4.57 \mathrm{~h}$. The semi-log plot of nondimensional time scale $t / \tau$ versus $\left(z_{m}\right)_{s} / h_{s}$ given in Figure 8 indicates that the maximum scour depth for a given time, $\left(z_{m}\right)_{s}$, varies logarithmically with time over the range of durations studied as similar to the results obtained in Hahn and Lyn (2010). Regression analysis of the data of the present study for non-dimensional scour depth $\left(z_{m}\right)_{s} / h_{s}$ led to the following equation:

$$
\frac{\left(z_{m}\right)_{s}}{h_{s}}=1.28\left(\frac{t}{\tau}\right)^{0.05}
$$

with a determination coefficient of $R^{2}=0.69$.

The location of the maximum scour depth $\left(x_{m}\right)_{s}$ is almost constant and for $V_{b} / V_{c}=1.07$ and 1.18 it slightly varies around the value of $\left(x_{m}\right)_{s} / L \approx 0.2$ as depicted from Figure 9. Nevertheless, the location moves about $\left(x_{m}\right)_{s} / L \approx 1.0$ for $V_{b} / V_{c}=1.60$ and 1.77 indicating significance of flow intensity and turbulence under the bridge deck on the scour depth location.

The maximum deposition height $\left(z_{m}\right)_{d} / h_{s}$ decreases with time. Figure 10 shows the general trend for all data used in the analysis. Except low values of non-dimensional time parameter of $t / \tau$, it is evident that data of the different flowrates and bridge heights conform to a narrow band. Higher scatter on dune-like deposition heights can be observed at low $t / \tau$ values which are mainly due to flow instabilities resulted from the scour hole turbulence effect on dune-like bed forms at the start of scour-deposition process. This effect is limited as time elapses. The general trend shown by the figure implies that they can be represented by a single curve given by

$$
\frac{\left(z_{m}\right)_{d}}{h_{s}}=0.52\left(\frac{t}{\tau}\right)^{-0.078}
$$

with a relatively low determination coefficient of $R^{2}=0.42$.

Figure 11 shows that the location of the non-dimensional maximum deposition height $\left(x_{m}\right)_{d} / L$ varies with nondimensional time $t / \tau$ over the range of experimental conditions. Flow intensity under the bridge deck $V_{b} / V_{c}$ is significant on the non-dimensional deposition location. The location moves further downstream sections with higher flow intensities as shown in Fig. 11. It can be inferred from Fig. 11 that $\left(x_{m}\right)_{d} / L$ values vary between 7 and 10.5 at the end of the test duration within the limits of experimental conditions applied.

\subsubsection{Design equation for $\left(z_{m}\right)_{s}$}

Data used in the analysis of the maximum scour depth $\left(z_{m}\right)_{s}$ cover data obtained from this study together with the data published by Arneson (1997) and Umbrell et al. (1998). Figure 12 shows the plot of non-dimensional parameters of $\left(h_{b}+\left(z_{m}\right)_{s}\right) / h_{a}$ versus $V_{b} / V_{c}$ for all data used in the analysis. For consistency, presence of pier and 
overflow cases were excluded from Arneson's and Umbrell's data set, respectively. Applying any regression analysis model including all data sets leads to underpredict observed data due to high scatter nature of data used mainly as a result of unclear or insufficient experimental durations in order to obtain the maximum scour depth. Lyn (2008) also criticized test durations of Arneson's and Umbrell's data set in this respect. In Fig. 12, it should be noted that vertical contraction effect on scour mechanism is considered with both flow intensity under the bridge deck section $V_{b} / V_{c}$ and bridge submergence (without overflow) $h_{b} / h_{a}$. When upper envelope lines are drawn on Fig. 12 passing through the maximum $\left(h_{b}+\left(z_{m}\right)_{s}\right) / h_{a}$ values, two linear tendencies can be observed on the basis of $V_{b} / V_{c}$; i.e. $V_{b} / V_{c}<1$ and $V_{b} / V_{c} \geq 1$. The envelope plotted leads to a set of simple linear equations as follows (Eq. 10) that can be used for predicting design depth of scour in a pressurized flow under bridge decks. Equation (10) includes the effect of $h_{b} / h_{a}$ on scours mechanism and is simple in application to find a value for design purposes.

$$
\begin{array}{ll}
\frac{\left(h_{b}+\left(z_{m}\right)_{s}\right)}{h_{a}}=0.65+0.5\left(\frac{V_{b}}{V_{c}}\right) & \text { for } 0.5 \leq \frac{V_{b}}{V_{c}}<1 \\
\frac{\left(h_{b}+\left(z_{m}\right)_{s}\right)}{h_{a}}=1.025+0.125\left(\frac{V_{b}}{V_{c}}\right) & \text { for } 1 \leq \frac{V_{b}}{V_{c}} \leq 1.8
\end{array}
$$

Equation (10) is valid for the conditions under which the experiments were conducted in this study and earlier studies.

\subsection{Unsteady flow}

In this section, the unsteady flow (step-wise hydrographs) experimental results are discussed in details. The effect of time to peak $\left(t_{p}\right)$ on scour and dune-like deposition under various hydrographs are investigated. In the unsteady flow experiments, general observations show that the scour and deposition profiles are self-similar. Unsteady flow experiments characterized by the stepwise hydrographs were compared with the steady flow case of maximum peak discharge $Q_{p}=50 \mathrm{l} / \mathrm{s}$ and $55 \mathrm{l} / \mathrm{s}$ with $T=8 \mathrm{~h}$. The scour and dune-like depositional profiles developed at the end of peak-flow discharges are measured for all stepwise hydrographs (U1-U8 as given in Figure 3) with peak-flow velocities of $\left(V_{a}\right)_{p}=0.266 \mathrm{~m} / \mathrm{s}$ and $\left(V_{a}\right)_{p}=0.286 \mathrm{~m} / \mathrm{s}$ corresponding to $Q_{p}=501 / \mathrm{s}$ and $Q_{p}=551 / \mathrm{s}$, respectively, but different time to peak values of $t_{p}=240,320,360$, and 420 minutes.

The final (end) scour depths for almost all unsteady tests are less than the maximum scour depths for the steady flow conditions (Figure 13a). Similar to steady flow conditions, higher flow intensities or peak discharge values $\left(Q_{p}\right)$ cause higher maximum scour depths in unsteady flow conditions. In addition, effect of time to peak 
discharge, $t_{p}$, on the maximum scour depth was limited for all cases. As expected, effect of $t_{p}$ on scour depth evolution is not of great importance as similar in the studies on pier scour under flood waves (Chang et al. 2004, Schillinger and Khan, 2013). Experimental results indicate that multiple smaller flood events do not cause greater scour depth than the larger flood events that cause equilibrium scour depths. Figure $13 \mathrm{~b}$ shows that for all stepwise hydrographs studied in the unsteady flow conditions the location of the maximum scour depths are slightly less than the scour depths obtained from the steady flow cases.

Profiles of dune-like bed forms along the downstream of the bridge deck are also measured in the unsteady flow conditions. Variations of $t_{p} / T$ with maximum deposition height normalized by bridge opening height (i.e $\left.\left(z_{m}\right)_{d} / h_{b}\right)$ and its corresponding location normalized by bridge width (i.e. $\left.\left(x_{m}\right)_{d} / L\right)$ are plotted in Figures 14 a and $14 \mathrm{~b}$, respectively. It can be inferred from Figure 14a that the maximum deposition heights in unsteady cases are higher than the steady flow deposition heights. Approaching flow intensity $V_{a} / V_{c}$ and time to peak ratio $t_{p} / T$ have limited effect on the maximum deposition heights. In Figure 14b, it is observed that locations of the maximum deposition heights in unsteady flows are less than the values of steady flow conditions. Comparing with the steady flow conditions, the locations are $10-30 \%$ less in unsteady cases showing a trend of decrease as the flow intensity decreases.

\section{Conclusions}

An experimental study were conducted using various experimental combinations with the duration up to $32 \mathrm{~h}$ to investigate the temporal variation scour progress and downstream sediment deposition in steady flow conditions. A single sediment size, four different approach flow velocities corresponding to degree of bridge deck submergences and two bridge opening height were used in the experimental program. Moreover, for the unsteady flow conditions, four stepwise hydrographs were studied to analyze flow unsteadiness on pressurescour depth and downstream deposition profiles. Within the range of experiments, the following conclusions can be drawn from the results of the present experimental study:

1) Scour and dune-like deposition profiles are $2 \mathrm{D}$ and self-similar as time elapses in steady flow conditions and four stepwise hydrographs (unsteady flow) studied.

2) Under steady flow experiments, limits of scour hole developed covered a horizontal distance of $-0.5<x / L<1.5$ for $h_{b} / h_{a} \approx 0.6$ and $0<x / L<3.5$ for $h_{b} / h_{a} \approx 0.4$ at the end of the test duration. The location of the maximum scour 
depth $\left(x_{m}\right)_{s}$ is almost constant and slightly varies around the value of $\left(x_{m}\right)_{s} / L \approx 0.2$ for $h_{b} / h_{a} \approx 0.6$. Nevertheless, the location moves about $\left(x_{m}\right)_{s} / L \approx 1.0$ for $h_{b} / h_{a} \approx 0.4$.

3) The extent of deposition zone developed between $1.5<x / L<8.1$ for $h_{b} / h_{a} \approx 0.6$. The deposition zone extends further downstream for $h_{b} / h_{a} \approx 0.4$.

4) Equation (10) is proposed to estimate a design value for predicting the maximum scour depth $z_{s}$ based on the analysis of data from the experiments as well as from the earlier studies. The derivation of Eq.(10) involves two important parameters: flow intensity under the bridge deck section $V_{b} / V_{c}$ and bridge submergence $h_{b} / h_{a}$.

5) The scour depths for almost all unsteady tests are less than the maximum scour depths obtained from the steady flow conditions. Effect of time to peak $t_{p}$ on scour development is limited in unsteady flow conditions. The maximum deposition height locations are $10-30 \%$ less in unsteady cases when compared with the steady cases.

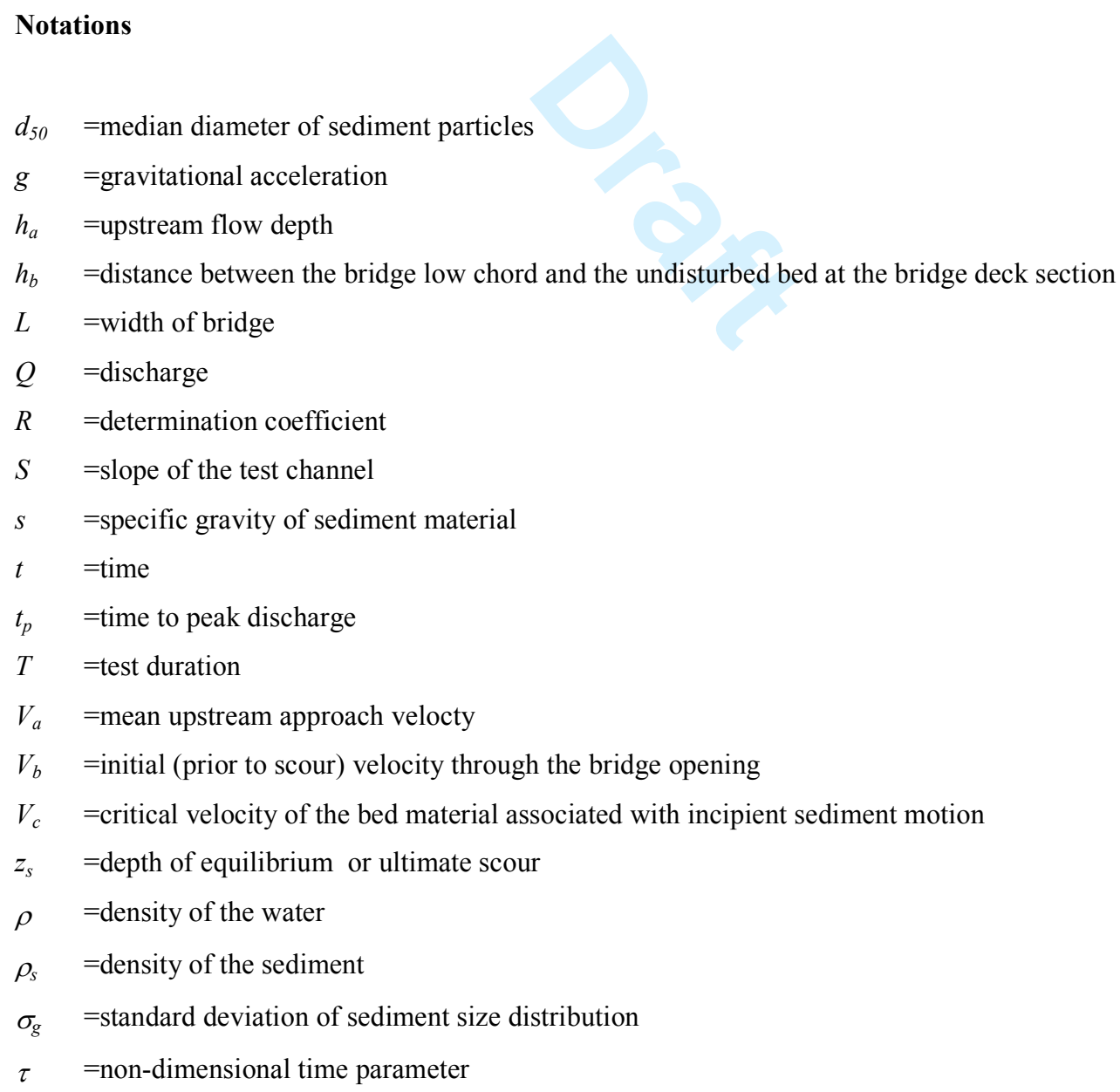




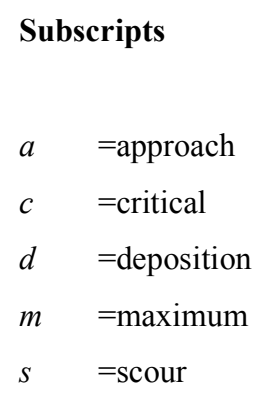

\section{References}

Abed, L.M. 1991. Local scour around bridge piers in pressure flow. PhD dissertation. Colorado State Univ. Fort Collins, Colo.

Arneson, L.A. 1997. The effect of pressure-flow on local scour in bridge openings. PhD Thesis. Dept. of Civil Engineering, Colorado State Univ. Fort Collins, Colo.

Chang, W.Y., Lai, J.S., \&Yen, C.L. 2004. Evolution of scour depth at circular bridge piers. Journal of Hydraulic Engineering, ASCE, 130(9):905-913.

Guo, J., Kerenyi, K., \& Ortiz, J.P.E. 2009. Bridge pressure flow scour for clear water conditions. FHWA-HRT09-041, United States Department of Transportation, Washington, DC.

Hahn, E.M. \& Lyn, D.A. 2010. Anomalous contraction scour? Vertical-contraction case. Journal of Hydraulic Engineering, ASCE, 136(2):137-141.

Hager, W.H. \& Unger, J. 2010. Bridge pier scour under flood waves. Journal of Hydraulic Engineering, ASCE, 136(10):842-847.

Jones, J.S., Bertoldi, D.A. \& Umbrell E.R. 1993. Preliminary studies of pressure-flow scour. ASCE Conf. on Hydr. Engrg., ASCE, Reston, Va.

Lai, J.S., Chang, W.Y., \& Yen, C.L. 2009. Maximum local scour depth at bridge piers under unsteady flow. Journal of Hydraulic Engineering, ASCE, 135(7):609-614.

Lu, J.Y., Hong, J.H., Su C.C., Wang, C.Y., \& Lai, J.S. 2008. Field measurements and simulation of bridge scour depth variations during floods. Journal of Hydraulic Engineering, ASCE, 134(6):810-821.

Lyn, D.A. 2008. Pressure-flow scour: A reexamination of the HEC-18 equation. Journal of Hydraulic Engineering, ASCE, 134(7):1015-1020.

Melville, B.W. 2014. Scour at various hydraulic structures: Sluice gates, submerged bridges, low weirs. Hydraulic Structures and Society: Engineering Challenges and Extremes, $5^{\text {th }}$ International Symposium on Hydraulic Structures, Brisbane, Australia.

Oliveto, G. \& Hager, W.H. 2005. Further results to time-dependent local scour at bridge elements. Journal of Hydraulic Engineering, ASCE, 131(2):97-105.

Schillinger, M.W, \& Khan A.A. 2013. Temporal pier scour evolution under stepped hydrographs. Sediment Transport Monitoring, Modeling and Management: Edited by Khan A.A. \& Wu W., Nova Publishers, N.Y.

Umbrell, E.R., Young, G.K., Stuart, M.S. \& Jones, J.S. 1998. Clear-water contraction scour under bridges in pressure flow. Journal of Hydraulic Engineering, ASCE, 124(2):236-240. 
Zhai, Y. 2010. Time-dependent scour depth under bridge-submerged flow. Thesis presented in partial fulfillment of requirements for MS degree, the Graduate Collage at the University of Nebraska. 
Table 1. Flow, sediment, and geometrical conditions used in experimental study

\begin{tabular}{lcc}
\hline Parameter & Steady flow & Unsteady flow \\
\hline$V_{a}(\mathrm{~m} / \mathrm{s})$ & $0.232-0.286$ & $0.222-0.266$ \\
$h_{b}(\mathrm{~m})$ & $0.050,0.075$ & 0.075 \\
$h_{a}(\mathrm{~m})$ & $0.115-0.131$ & $0.120-0.125$ \\
$h_{s}(\mathrm{~m})$ & $0.045-0.078$ & $0.045-0.050$ \\
$L(\mathrm{~m})$ & 0.30 & 0.30 \\
$d_{50}(\mathrm{~mm})$ & 0.90 & 0.90 \\
$\sigma$ & 1.29 & 1.29 \\
$T(\mathrm{~h})$ & 32 & 8 \\
$(F r)_{\mathrm{a}}$ & $0.23-0.25$ & $0.20-0.24$ \\
$h_{s} / d_{50}$ & $50-87$ & 55 \\
\hline
\end{tabular}

$T=$ Maximum test duration $(\mathrm{h}) ;(F r)_{a}=$ approach flow Froude number defined as $(F r)_{a}=V_{a} /\left(g h_{a}\right)^{0.5}$ 


\section{List of Figures}

Figure 1. Definition sketch of scour due to pressurized flow under a bridge deck

Figure 2. a) photograph of test channel and bridge deck model used in experimental study (looking from upstream) b) scour profile under bridge deck section during a test

Figure 3. Stepwise hydrographs used in the experimental study

Figure 4. Temporal development of scour hole and deposition profiles for $h_{b}=7.5 \mathrm{~cm}$ under steady flow conditions of a) $\mathrm{Q}=50 \mathrm{lt} / \mathrm{s}$ and b) $\mathrm{Q}=55 \mathrm{lt} / \mathrm{s}$

Figure 5. Temporal development of scour hole and deposition profiles for $h_{b}=5 \mathrm{~cm}$ under steady flow conditions of a) $\mathrm{Q}=50 \mathrm{lt} / \mathrm{s}$ and b) $\mathrm{Q}=55 \mathrm{lt} / \mathrm{s}$

Figure 6. Developments of the maximum scour depths under clear-water steady flow conditions for constant bridge heights of a) $\left.h_{b}=5 \mathrm{~cm}, b\right) h_{b}=7.5 \mathrm{~cm}$

Figure 7. Developments of the maximum scour depths under clear-water steady flow conditions for constant approaching flow intensities of a) $\mathrm{V}_{\mathrm{a}} / \mathrm{V}_{\mathrm{c}}=0.64$, b) $\mathrm{V}_{\mathrm{a}} / \mathrm{V}_{\mathrm{c}}=0.69$

Figure 8. Variation of nondimensional the maximum scour depth parameter $\left(z_{m}\right)_{s} / h_{s}$ with nondimensional time scale $t / \tau$ under clear-water steady flow conditions

Figure 9. Variation of nondimensional the location of maximum scour depth parameter $\left(x_{m}\right)_{s} / L$ with nondimensional time scale $t / \tau$ under clear-water steady flow conditions

Figure 10. Variation of nondimensional the maximum deposition height parameter $\left(z_{m}\right)_{d} / h_{s}$ with nondimensional time scale $t / \tau$ under clear-water steady flow conditions

Figure 11. Variation of nondimensional the location of maximum deposition height parameter $\left(x_{m}\right)_{d} / L$ with nondimensional time scale $t / \tau$ under clear-water steady flow conditions

Figure 12. Variation of bridge submergence with flow intensity

Figure 13. Effect of $t_{p} / T$ on a) the maximum scour depth and b) the location of the maximum scour depth for $\mathrm{h}_{\mathrm{b}}=7.5 \mathrm{~cm}$

Figure 14. Effect of $t_{p} / T$ on a) the maximum deposition height and b) location of the maximum deposition height for $h_{b}=7.5 \mathrm{~cm}$ 


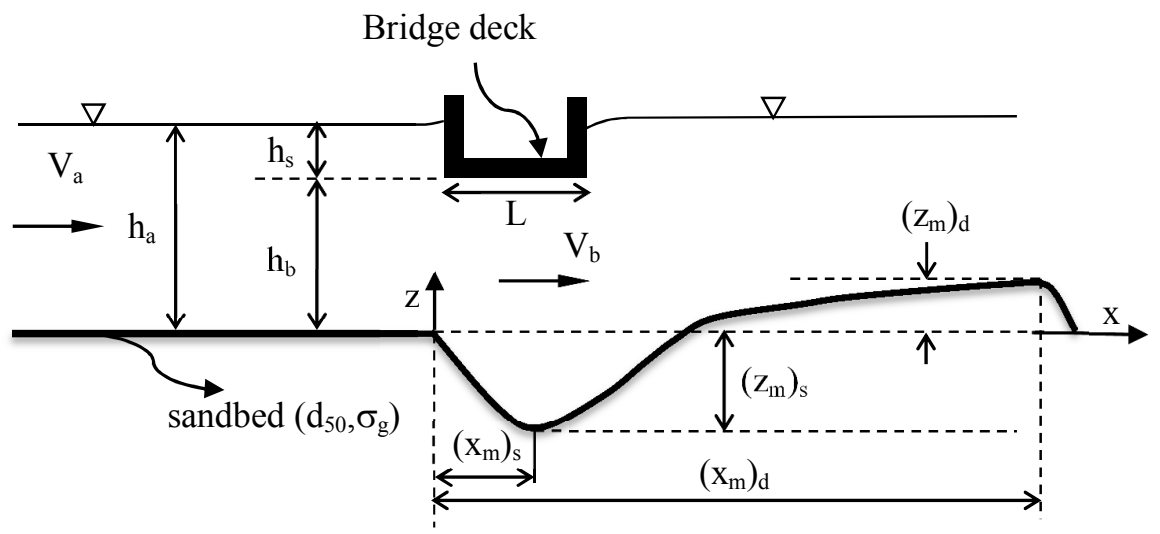




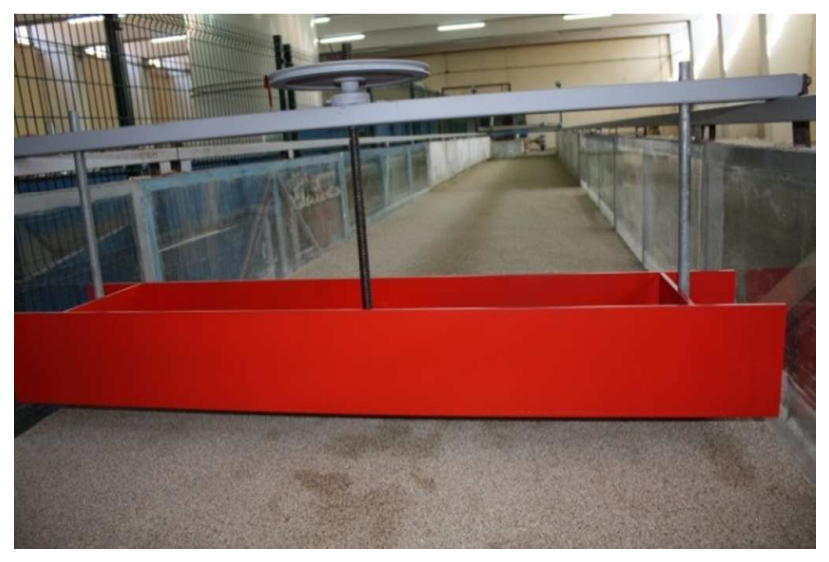

a)

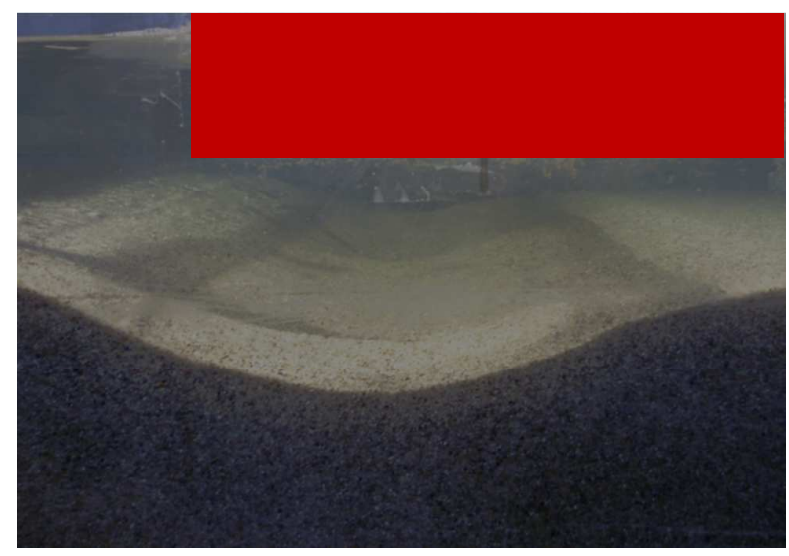

b) 


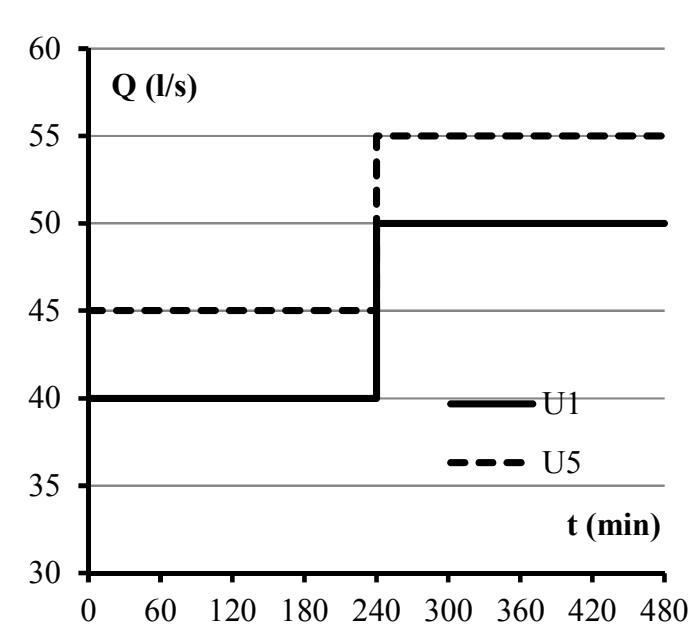

a)U1 and U5

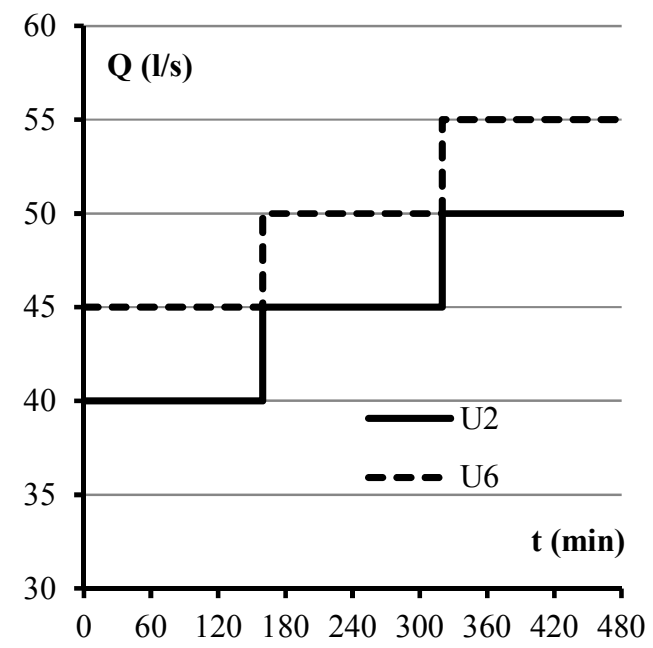

b)U2 and U6

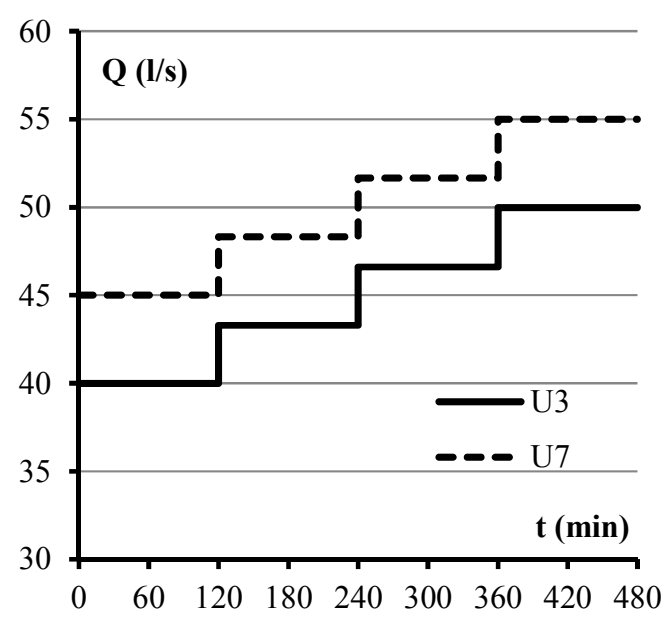

c)U3 and U7

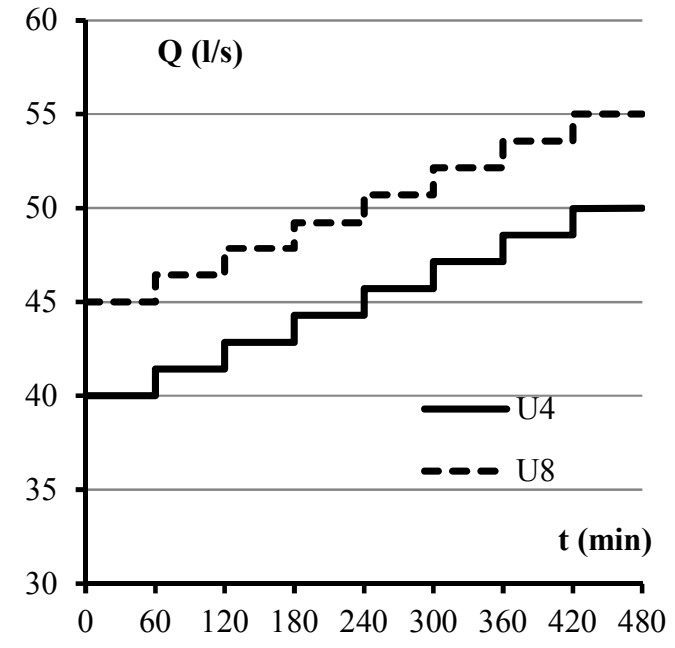

d)U4 and U8 


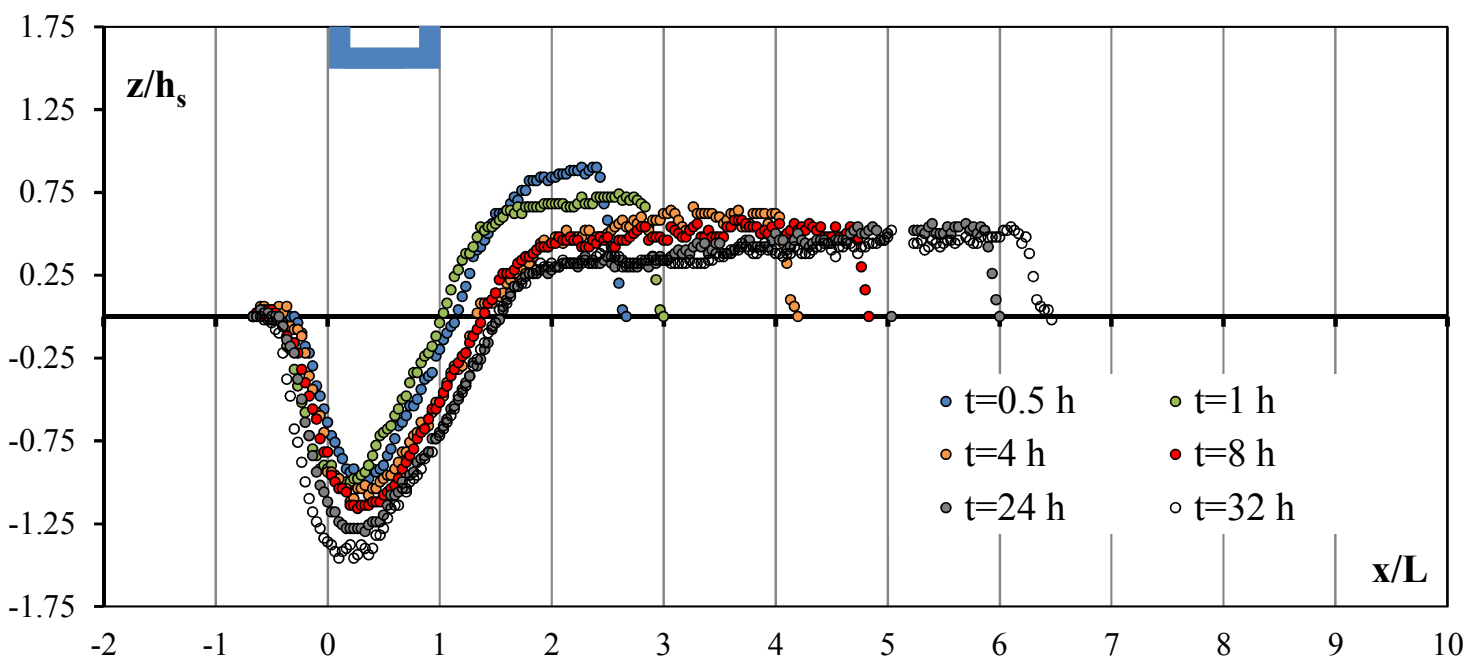

a)

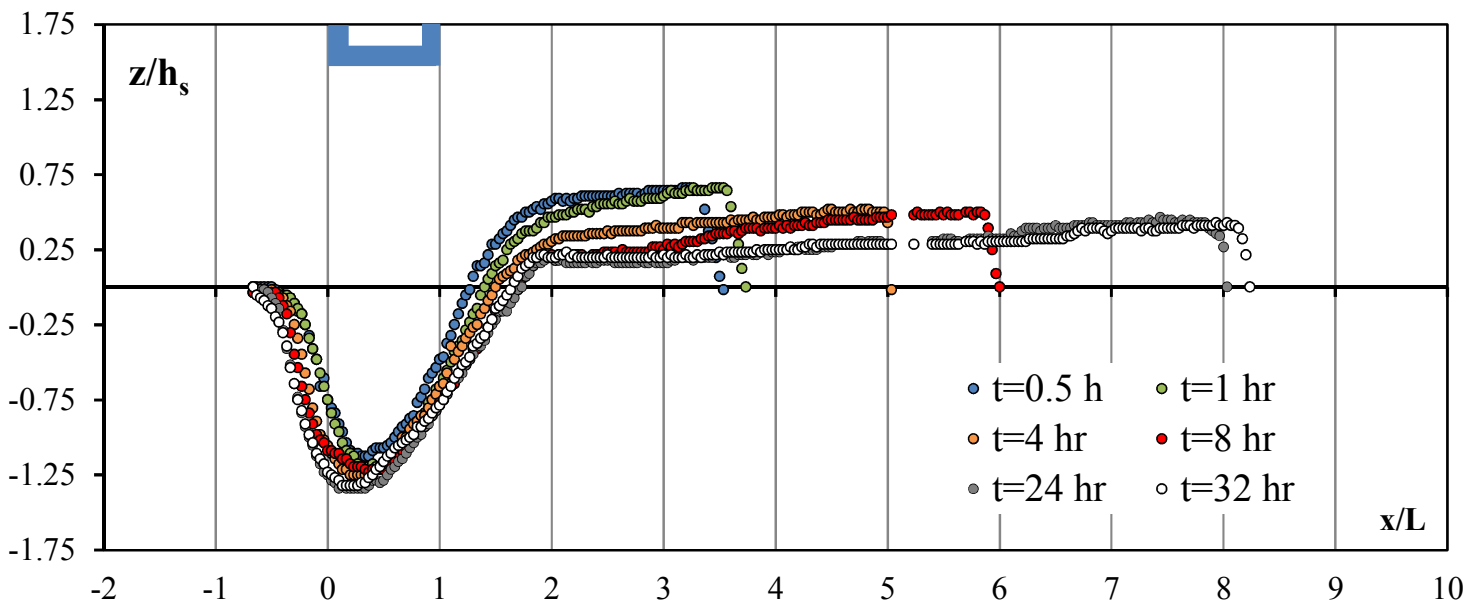

b) 


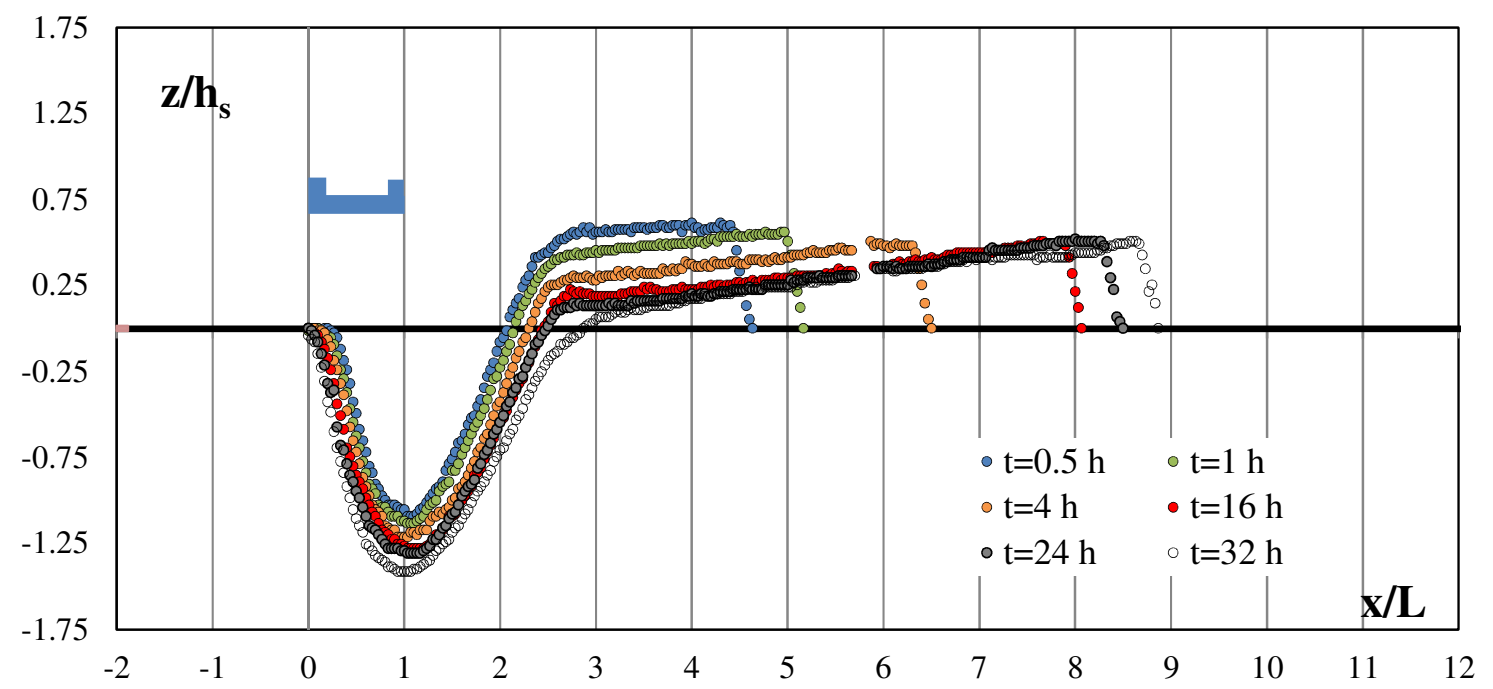

a)

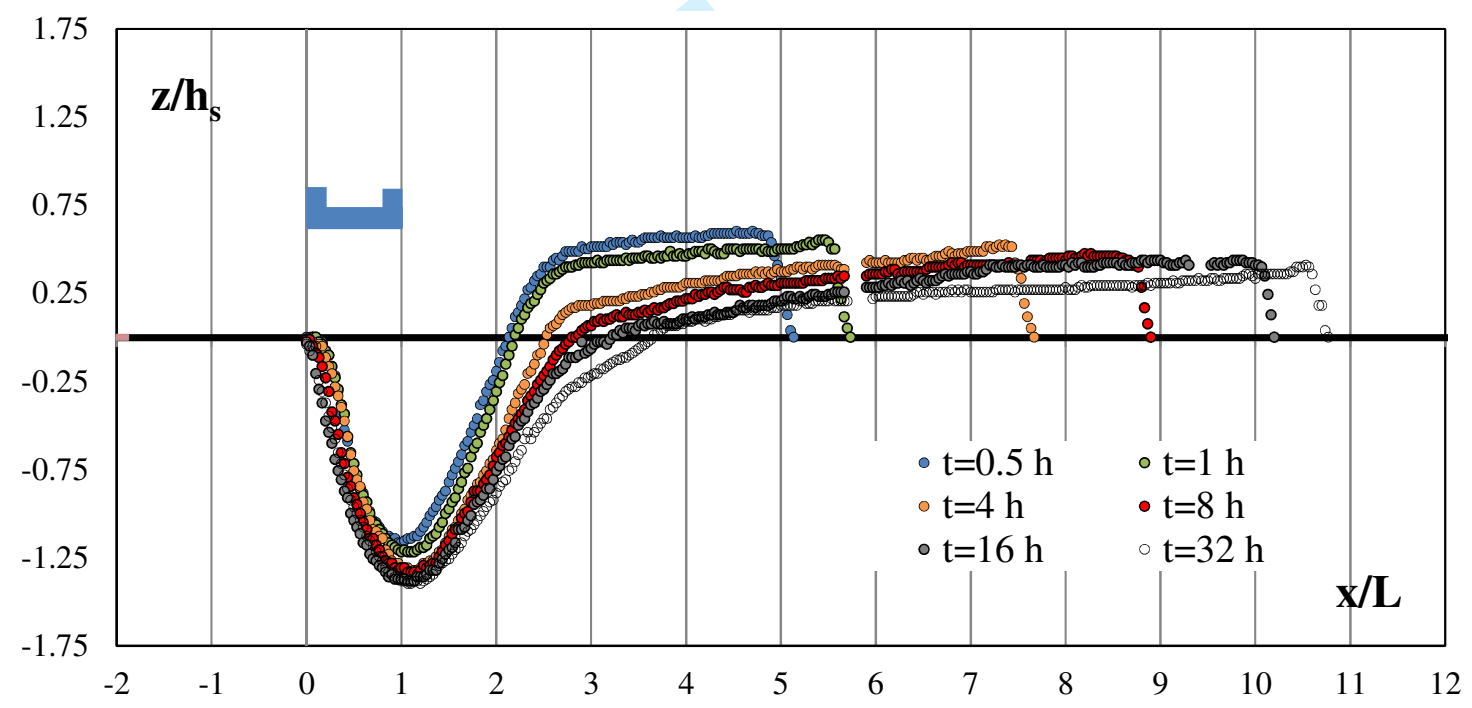

b) 

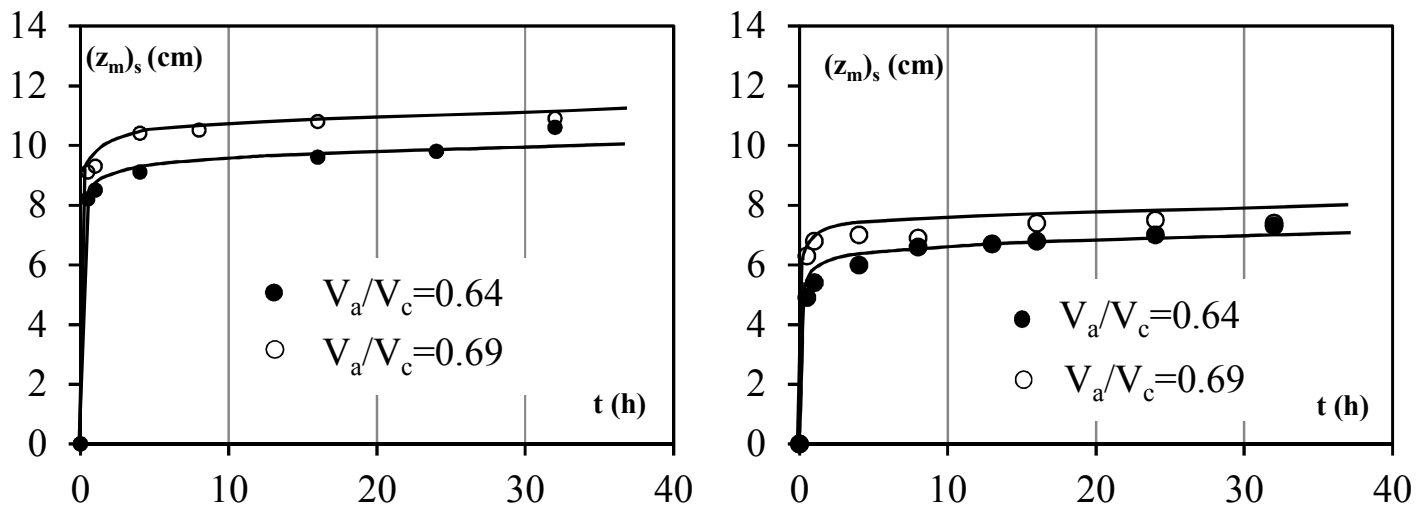

a)

b) 

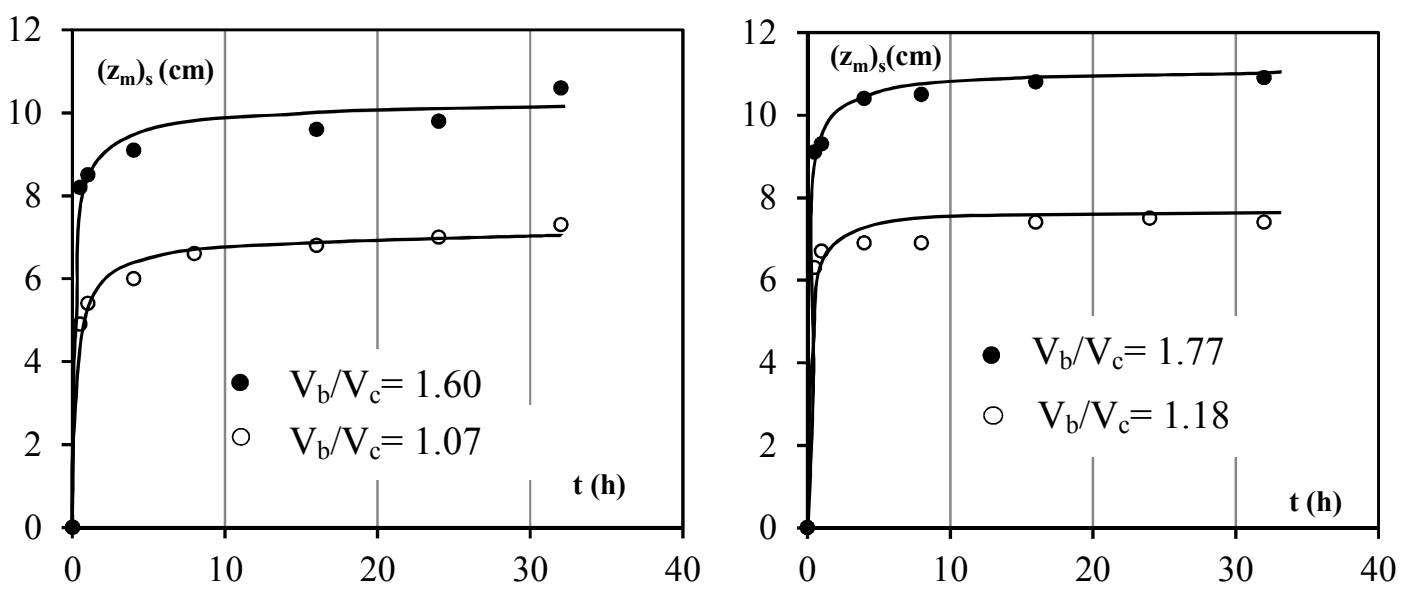

a)

b) 


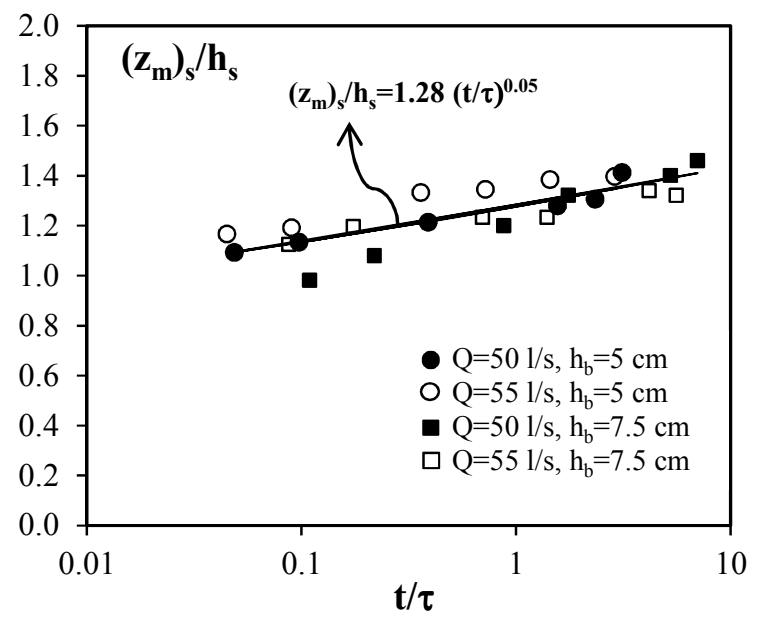

https://mc06.manuscriptcentral.com/cjce-pubs 


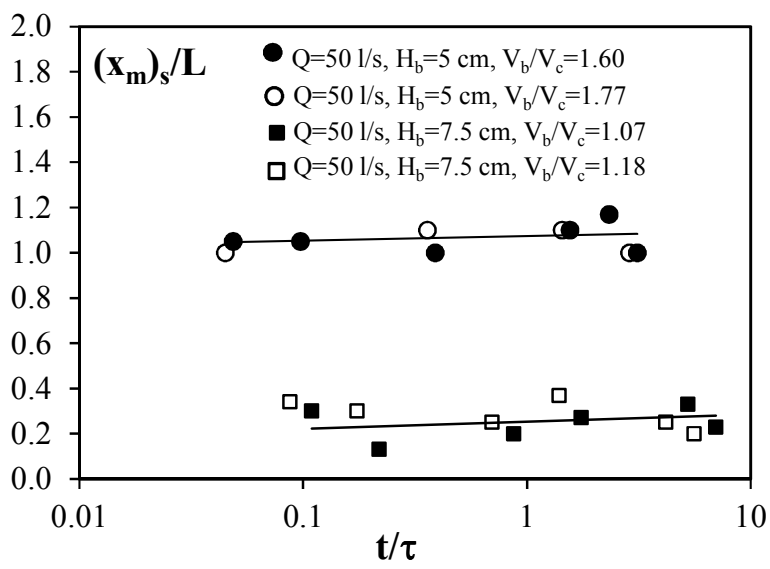

https://mc06.manuscriptcentral.com/cjce-pubs 


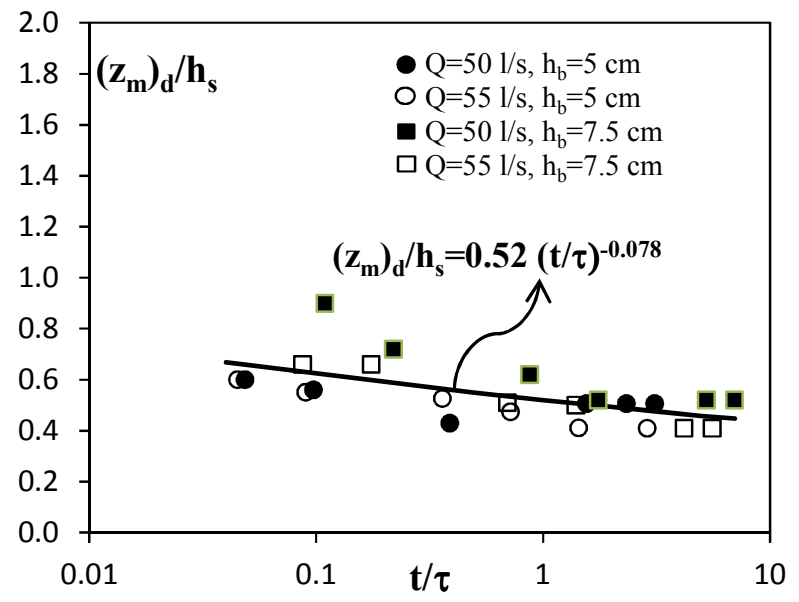

https://mc06.manuscriptcentral.com/cjce-pubs 


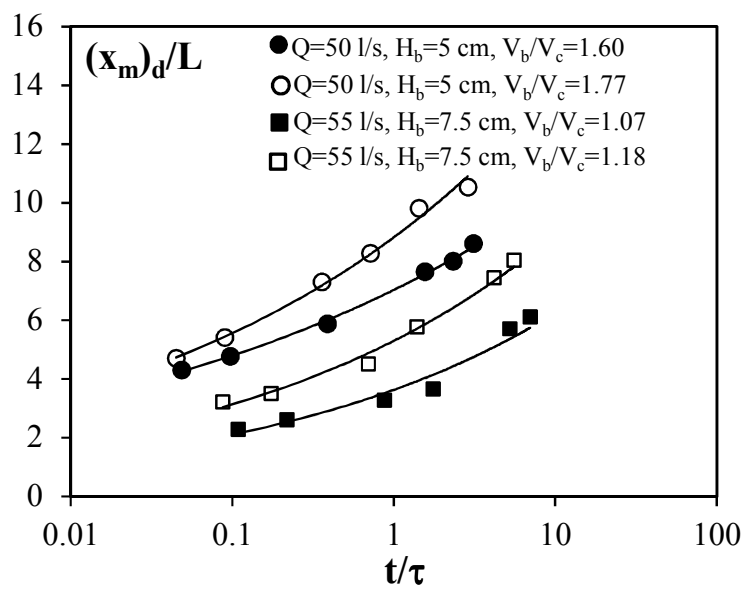

https://mc06.manuscriptcentral.com/cjce-pubs 


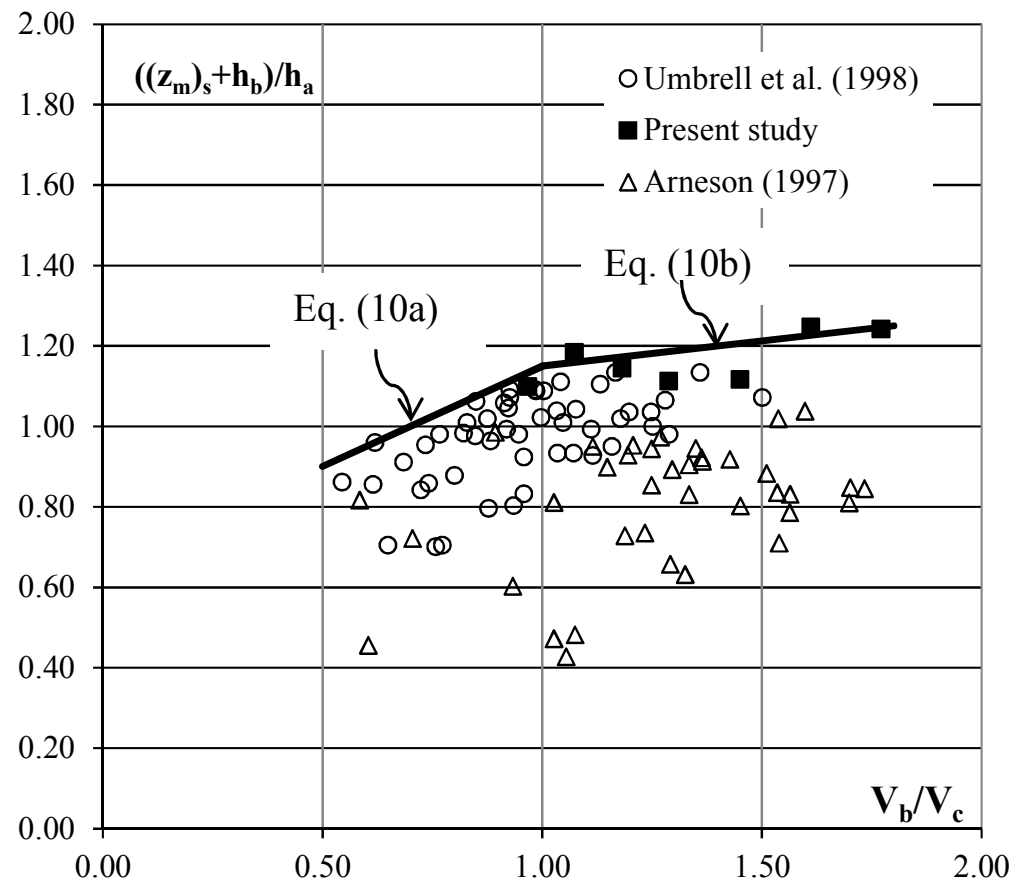




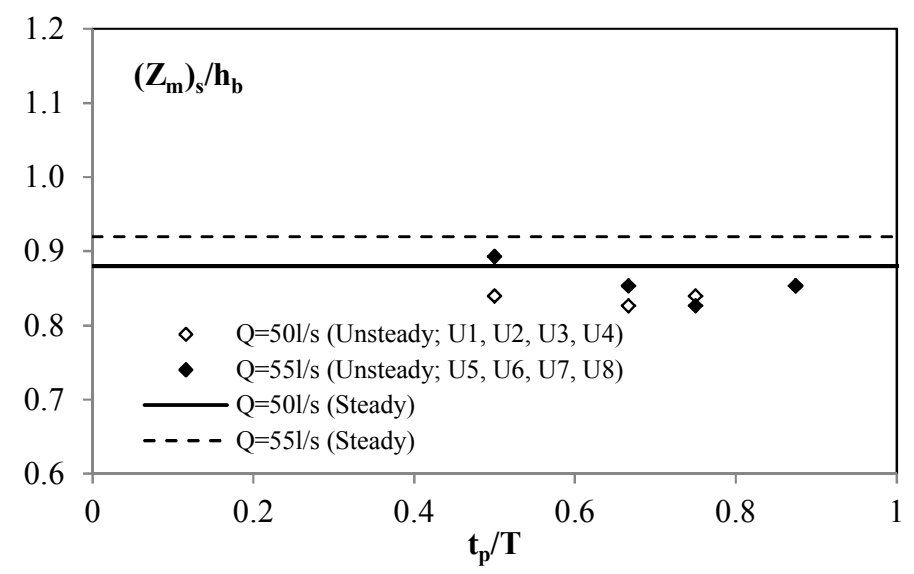

a)

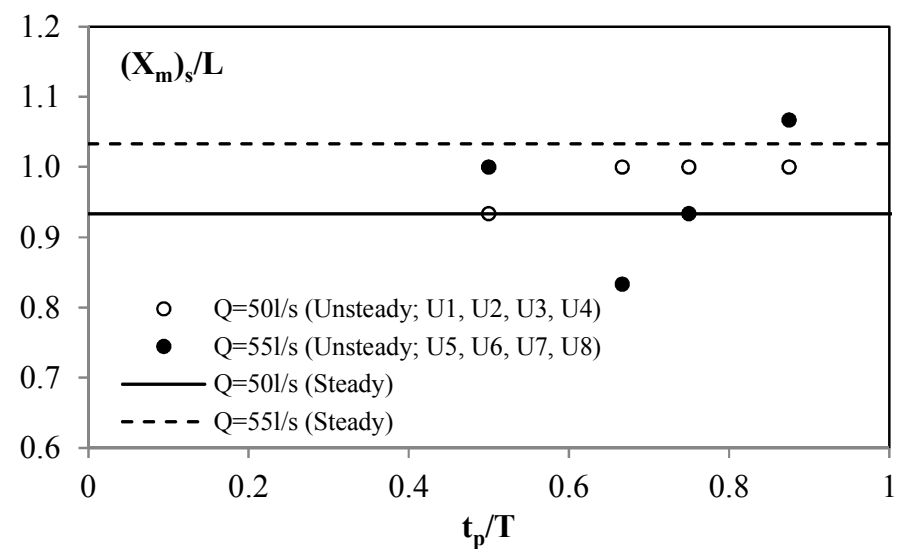

b) 


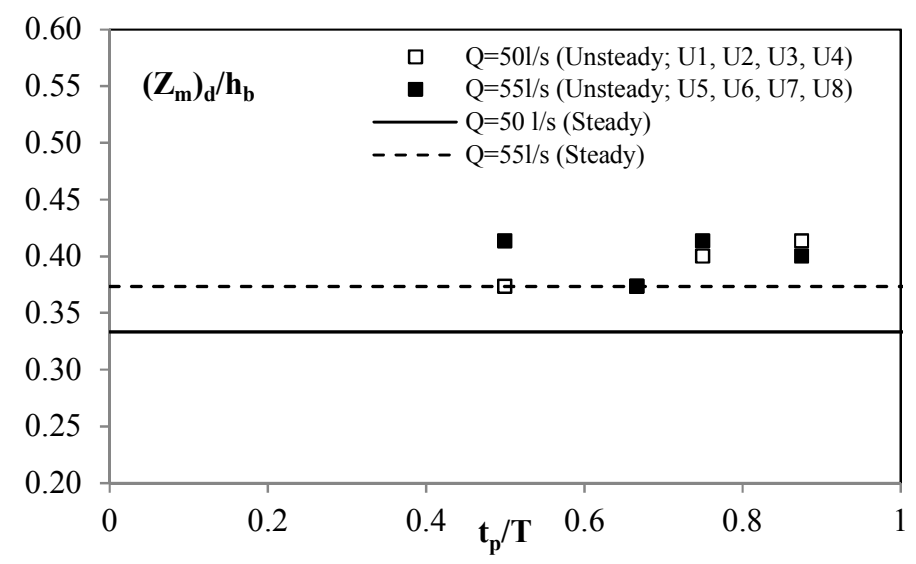

a)

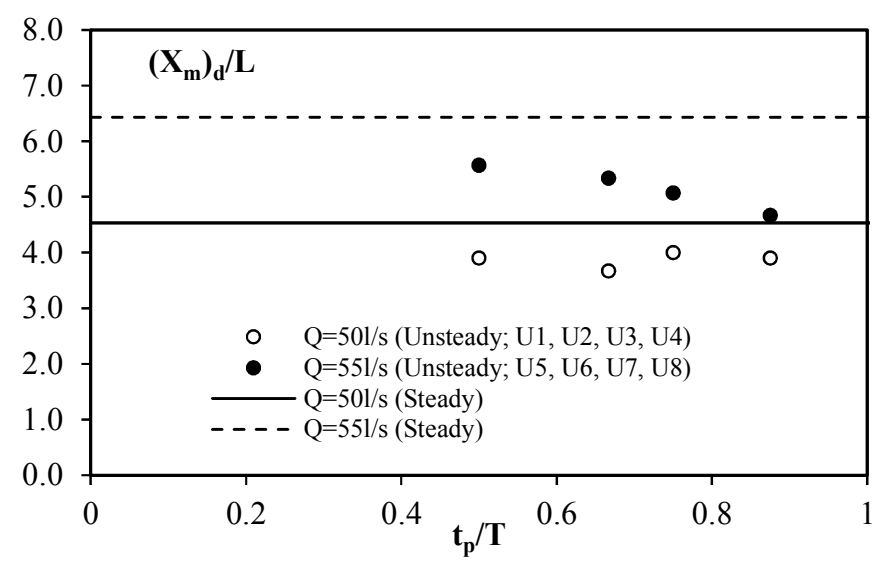

b) 